\title{
Vodka on ice? : Unveiling Russian media perceptions of the Arctic
}

\section{Gritsenko, Daria}

2016

Gritsenko , D 2016 , ' Vodka on ice? Unveiling Russian media perceptions of the Arctic ' , Energy Research \& Social Science, vol. 16 , no. June2016, pp. 8-12 . https://doi.org/10.1016/j.erss.2016.03.012

http://hdl.handle.net/10138/297772

https://doi.org/10.1016/j.erss.2016.03.012

cc_by_nc_nd

acceptedVersion

Downloaded from Helda, University of Helsinki institutional repository.

This is an electronic reprint of the original article.

This reprint may differ from the original in pagination and typographic detail.

Please cite the original version. 


\title{
Vodka on ice? Unveiling Russian media perceptions of the Arctic
}

\author{
Daria Gritsenko
}

https://doi.org/10.1016/j.erss.2016.03.012

\begin{abstract}
This article describes Russian Arctic policy agendas as they have been reflected in mainstream Russian media outlets. The research was based on modeling topic structures of three federal and three regional newspapers. Topic modeling was performed with the unsupervised LDA algorithm and complemented with hand labelling of topics. Data was collected by retrieval of relevant newspaper articles from the media database Integrum for the period 2011-2015 ( $\mathrm{N}=611$ ); the corpus was further divided in two periods (2011-2013 and 20142015) to account for the potential effect of the Ukrainian crisis on agenda-setting. Both federal and regional newspapers were found to have been mostly concerned with the development of hydrocarbon resources, as coverage of this topic was the largest during both periods. However, during the second period (2014-2015), the repercussions of the Ukrainian crisis, namely the economic sanctions and securitization, gained significant attention while marginalizing other topics. The results of this analysis may serve as a foundation for application of sentiment analysis to allow an in-depth understanding of topic salience and impact on public opinion.
\end{abstract}

\section{Keywords}

Russia

Arctic

Topic modeling

Energy policy

\section{Introduction: Russia in the Arctic}

The Arctic is of particular importance to Russia. The core areas of contemporary Russian Arctic policy are energy, transport, and security. After the collapse of the Soviet Union, economic development in the Arctic has significantly slowed [1], yet the past fifteen years witnessed a revival of Russia's commercial activity in the High North. Rich natural Arctic resource deposits located on- and offshore, as well as the commercial potential of the Northern Sea Route (NSR), were declared as a guarantee of Russia's future economic prosperity and influence in world affairs [2].

Today, the Arctic is Russia's significant "resource base" as Russian Arctic and sub-Arctic regions produce $98 \%$ of Russia's diamonds, $90 \%$ of its oil, gas, nickel, cobalt and platinum, $60 \%$ of its copper, and $24 \%$ of its goldthe extraction of which provides 11\% of Russia's GDP [3]. Operated since 2013 by Gazpromneft, Prirazlomnoye is the first commercial offshore development in the Arctic. Construction of the Yamal LNG 
project, including extraction and liquefaction facilities, the port of Sabetta, and a specialized fleet, also progresses with significant speed; regular operation is expected to commence in 2017.

A key role allocated to the Arctic in the Russian economic and geopolitical strategies that formed under President Putin's administration has provoked mixed reactions among Arctic experts. In academic assessments, the role of Russia can vary from being a "troublemaker" pursuing aggressive and expansionist politics that will eventually lead to conflict [4], [5], [6], [7] to acting as a "status quo seeker" interested in maintaining the region as an area of international cooperation and in preserving regional stability for the sake of future economic development [8], [9], [10], [11]. The literature highlights a paradoxical situation: Though Russia is seen as the most probable source of geopolitical instability, it is also perceived as the country with the highest interest in a stable Arctic.

The escalation of the Ukrainian crisis, especially Russia's intervention in Ukraine in early 2014, has raised questions regarding the future of international cooperation in the Arctic [12]. Norway has suspended its bilateral military cooperation with Russia [13] and Canada canceled its participation in an Arctic Council meeting held in M oscow in April 2014 [14]. In the light of the situation in Eastern Ukraine, increasing Arctic militarization has been perceived as a sign of Russia's readiness to use military force to achieve its geopolitical ambitions [15]. The economic sanctions imposed by the European Union (EU), the United States, and some other countries since spring of 2014 (including restrictions on trade in certain types of energy technology, access to credit, and asset freezing) have created constraints for the implementation of Arctic energy projects previously envisaged as cooperation between Russian and Western companies [16], [17]

\section{Research agenda: the Arctic in Russian policy and media}

The current Russian approach to exploration and exploitation of the vast northern territories is shaped through multiple policy instruments that incorporate Arctic policy priorities (Table 1). Ambitious plans presented by the Russian government for the next decade seek to transform the Arctic into a prosperous and economically sustainable part of the Russian state [18], an energy powerhouse [19], and a source of increased geopolitical power [20]. In order to improve administrative support for Arctic zone development and the maintenance of national security, the State Commission for the Development of the Arctic was established in 2015.

Table 1. Russian Policy Instruments for Arctic Development 2008-2014 (source: author).

\begin{tabular}{|c|c|c|}
\hline Year & Document & Priorities \\
\hline 2008 & $\begin{array}{l}\text { Foundations of the State } \\
\text { Policy of the Russian } \\
\text { Federation in the Arctic Up } \\
\text { to and Beyond } 2020\end{array}$ & $\begin{array}{l}\text { Transformation of the Arctic into Russia's "foremost strategic base for natural } \\
\text { resources" by } 2020 . \\
\text { - } \\
\text { - develop three strategic resource bases: oil and natural gas, fisheries, } \\
\text { - maintain the Arctic as a zone of peace and cooperation } \\
\text { - } \quad \text { environmental protection } \\
\text { - } \quad \text { promotion of the Northern Sea Route (NSR) }\end{array}$ \\
\hline 2008 & $\begin{array}{l}\text { Transport Strategy of the } \\
\text { Russian Federation up to } \\
2030\end{array}$ & $\begin{array}{l}\text { Development of maritime activities in the Arctic, in particular refurbishing } \\
\text { the Northern Sea Route infrastructure (ice-class vessels, ice breakers, coastal } \\
\text { infrastructure, functioning border control and rescue service) }\end{array}$ \\
\hline
\end{tabular}




\begin{tabular}{|c|c|c|}
\hline 2009 & $\begin{array}{l}\text { Russian Energy Strategy up } \\
\text { to } 2030\end{array}$ & arctic region to be one of the key areas for future extraction of oil and gas \\
\hline 2009 & $\begin{array}{l}\text { Strategy for National } \\
\text { Security of the Russian } \\
\text { Federation until } 2020\end{array}$ & $\begin{array}{l}\text { Possession of energy resources in the Arctic is pivotal to the development of } \\
\text { national security, thus the need to improve border protection and related } \\
\text { infrastructure }\end{array}$ \\
\hline 2013 & $\begin{array}{l}\text { The Strategy for } \\
\text { Development of the Arctic } \\
\text { Zone of the Russian } \\
\text { Federation and National } \\
\text { Security up to } 2020\end{array}$ & $\begin{array}{l}\text { Arctic zone of the Russian Federation; 2) development of science and } \\
\text { technology; 3) creation of a modern information and telecommunications } \\
\text { infrastructure; 4) ensuring ecological safety; 5) international cooperation in } \\
\text { the Arctic; 6) military security, defense, and protection of the state border of } \\
\text { the Russian Federation in the Arctic. }\end{array}$ \\
\hline 2014 & $\begin{array}{l}\text { n Energy Strategy up } \\
5\end{array}$ & il and $10 \%$ of total gas \\
\hline 2014 & $\begin{array}{l}\text { State Program "Socio- } \\
\text { Economic Development of } \\
\text { the Arctic Zone of the } \\
\text { Russian Federation for the } \\
\text { Period until 2020" }\end{array}$ & $\begin{array}{l}\text { Umbrella document that includes a full list of activities from other RF state } \\
\text { programs implemented in the Arctic zone (e.g., "Development of Transport } \\
\text { System," "Reproduction and Use of Natural Resources," "Development of } \\
\text { Education," "The Development of Culture and Tourism," "The Protection of } \\
\text { the Population and Territories from Emergency Situations, Fire Safety and } \\
\text { Safety on Water Bodies"). }\end{array}$ \\
\hline
\end{tabular}

Some scholars have suggested that the Russian pursuit of the High North can best be interpreted as an identity-building project [21], [22], [23]. Kefferputz [24] demonstrated that the idea of reestablishing Russia as a "Great Arctic Power" has received popular support and increased the popularity of politicians at both federal and regional levels. However, little work has been done to investigate how the government's ambitious strategies and global economic and political trends are reflected in Russian mass media. In Wilson Rowe's study of Russia's media discourse on the Arctic in the widely read newspaper Rossiiskaya Gazeta, she demonstrated that media coverage framing the Arctic as a zone for cooperation rather than conflict grew steadily during 2008-2011, so that by 2011 articles with a conflict-oriented tone had almost disappeared [25]. No studies have been identified that sought to identify the topic structure of Russian media coverage on Arctic-related issues.

To redress this knowledge gap, this article describes the agendas of Russian Arctic policies as they are reflected in the Russian mainstream media outlets. Based on an analysis of 611 newspaper articles from six widely circulated newspapers, the study identified the central topics covered in the federal and regional press. This research agenda is relevant, as mainstream media in Russia is widely used as a tool for streamlining political agendas and "building the nation" [26].1 Analysis of topics discussed in mainstream newspapers provides an understanding of how Arctic policies are "served for domestic consumption" to the general public in Russia.

In order to explore a news corpus and describe the media agenda, defined here as a set of issues addressed in a media sample, the proposed methodological approach for this study is based on topic modeling. Topic modeling, a method extensively used in computer science, can uncover developments in media landscapes by revealing composition, structure, and change in relative weight of different topics over time and across large samples, without dwelling on the sentiment of the topics revealed (for an overview, see Ref. [29]). Despite this fact, topic modeling is a useful tool that allows for the automatic mapping of agendas within 
large textual data, thus avoiding the common methodological problems of insufficient and biased sampling [30].

\section{Data and method}

For the media analysis, six newspapers were selected: three federal level newspapers widely circulated in Russia and three regional newspapers issued in three Arctic regions (M urmansk, Yamal-Nenets Autonomous Okrug, and Yakutia). The selection criteria were readership and position in the Russian media landscape; the goal was to include the most widely read mainstream agenda-setting outlets. The federal newspapers are the state-owned newspaper of record Rossiiskaya Gazeta (Russian Gazette, RG); the leading daily business broadsheet Kommersant (Businessman), currently owned by Alisher Usmanov, the head of Gazprom's Gazprominvestholding subsidiary; and Izvestia (News Reports), a former Soviet newspaper of record currently enjoying a broad readership all over Russia for its extensive coverage of both socio-political and economic issues. Regional newspapers were selected from three Arctic regions that have dissimilar backgrounds. Vechernii Murmansk is a newspaper from Murmansk, the largest city in the Arctic and a strategic naval base of the Russian Northern Fleet as well as a commercial port. Krasnyi Sever is a primary media outlet in Yamal, Russia's largest gas province and currently a destination of substantial investment for the Yamal LNG project. Finally, Yakutia is a widely read Russian-language daily newspaper in Yakutia, a republic with well-developed extractive industries (diamonds, gold, oil, gas, coal, and other natural resources).

Having identified the newspapers, the full texts of publications for the period of 1 January, 2011-1 December, 2015 were pulled from the Russian media database Integrum by using two keywords: "Arctic" and "strateg*[/y/ic]." The resulting corpus included 611 publications (Table 2). The data were cleaned by removing meta-text and stop words (the most common words in the language, including interjections, prepositions, and the like). Next, each part of the corpus (federal and regional newspapers) was split into two periods: 1 January, 2011-31 December, 2013 (period 1) and 1 January, 2014-1 December, 2015 (period 2). The division line between the periods was decided in accordance with the escalation of the Ukrainian crisis that led to the deterioration of political relations between Russia and the West. 
Table 2. Composition of the final sample (source: author).

\begin{tabular}{|l|l|}
\hline Federal press & $\mathbf{3 0 0}$ \\
\hline Izvestia & 43 \\
\hline Kommersant & 89 \\
\hline Rossiiskaya Gazeta & 168 \\
\hline Regional press & $\mathbf{3 1 1}$ \\
\hline Vechernii Murmansk & 28 \\
\hline Krasnyi Sever & 178 \\
\hline Yakutia & 107 \\
\hline
\end{tabular}

Next, topic modeling was conducted using M ALLET software. Topic modeling is a technique that allows for finding and defining latent thematic structures (groups of tightly co-occurring words) in a document corpus. In this work, the Latent Dirichlet Allocation (LDA) algorithm was used, which is among the most widely used topic models [31]. LDA can best be described as a statistical model of language. Using the LDA algorithm allows for discovering a set of "topics"-or lexically similar groups recurring in the corpus-and the degree to which each document exhibits those topics. The algorithm assumes that there is a set of topics in a collection (the number is specified in advance), where a topic is formally defined as a distribution over a vocabulary.

One advantage of the LDA is that the analyst does not need to specify the topics in advance, so the outcome does not depend on the researcher's preconceptions. Rather, the topics are estimated from the texts. In this analysis, the algorithm was trained for six topics, that number having been established through empirical testing. This means that each word in the document was assigned to one of the six topics. As a result, each document exhibited those topics in different proportions. As the topics are not known in advance, a researcher must reliably label each of the topics. In this study, the internal semantic approach to estimating reasonable topic labels was used: reading a subset (ca. 5\%) of randomly chosen documents to discover whether the model meaningfully discriminated between different senses of the same or similar terms, and providing a description/label.

Two separate analyses were run: one for the federal and one for the regional media. At the interpretation stage, four topic models were compared: (1) federal newspapers during the first period, (2) federal newspapers during the second period, (3) regional newspapers during the first period, and (4) regional newspapers during the second period. Comparing the topic models allowed examination of the variation in newspapers' coverage of particular themes at both levels, and also revealed the dynamics of change in media coverage between the two periods.

\section{Results}


The results of the topic modeling for the federal and regional samples using a six-topic unsupervised solution are presented in Table 3. The two sets of topics display partially overlapping agendas; a particular similarity can be established between Topic \#3, Topic \#6, and to some extent Topic \#4 in both the federal and regional models. However, the topics were formulated from different angles. The regional newspapers tended to focus on the regional meaning of a given topic, whereas the federal newspapers showed them from the point of view of Russia and Russian companies as international actors. For instance, regional Topic \#3 dealt with the role of resource development in Russian Arctic regions in the context of overall Russian economic development. Topic \#3 from the federal model, essentially covering the same issue, focused on the broader potential of oil and gas development in the Russian Arctic. Topic \#6 in the regional model covered regional dimensions of mitigating the impact of Western sanctions, and federal Topic \#6 encompassed Western sanctions, import substitution, and securitization of the Arctic as a complex of issues that followed the Ukrainian crisis. The federal level newspapers focused on covering those topics that were within the competencies of federal authorities (resource exploration, infrastructure development, international partnerships, Arctic shipping and icebreaking). The regional newspapers tended to cover local politics (frequent mentioning of local politicians) and diverse issues in regional development and local welfare (exemplified in Topics \#1, \#2, \#5).

Table 3. Six topic solutions for federal and regional samples, unsupervised topic model, internal semantic labelling based on 20 highest-ranked terms per topic (source: author).

\begin{tabular}{|c|c|c|c|c|c|c|}
\hline & Topic 1 & Topic 2 & Topic 3 & Topic 4 & \begin{tabular}{|l|} 
Topic 5 \\
\end{tabular} & Topic 6 \\
\hline$\underset{t}{z}$ & $\begin{array}{l}\text { Regional } \\
\text { activities in the } \\
\text { Arctic }\end{array}$ & $\begin{array}{l}\text { Further } \\
\text { exploration and } \\
\text { partners }\end{array}$ & $\begin{array}{l}\text { Russian oil \& gas } \\
\text { development in } \\
\text { the Arctic }\end{array}$ & $\begin{array}{l}R \& D \quad \text { and } \\
\text { infrastructure } \\
\text { development }\end{array}$ & \begin{tabular}{|l|} 
Arctic \\
shipping
\end{tabular} & $\begin{array}{l}\text { Ukranian crisis } \\
\text { and sanctions }\end{array}$ \\
\hline 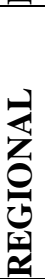 & $\begin{array}{l}\text { Welfare, } \\
\text { indigenous and } \\
\text { education } \\
\text { policies }\end{array}$ & \begin{tabular}{|l|} 
Regional \\
attractiveness \\
and potential
\end{tabular} & $\begin{array}{l}\text { Arctic regions in } \\
\text { Russian } \\
\text { economic } \\
\text { development }\end{array}$ & $\begin{array}{lr}\text { Research in } \\
\text { science } \\
\text { technology }\end{array}$ & \begin{tabular}{|l|} 
Issues in \\
regional \\
development
\end{tabular} & $\begin{array}{l}\text { Regional } \\
\text { development } \\
\text { strategies after } \\
\text { sanctions }\end{array}$ \\
\hline
\end{tabular}

Fig. 1 illustrates how the topic structure in federal press varied between the two periods. Throughout 20112015, articles in federal newspapers discussing Russia's Arctic policies were mostly concerned with the development of hydrocarbon resources (Topic \#3). During the first period (2011-2013), the topics of research and development, infrastructure, and Arctic shipping with an emphasis on icebreaking capacity occupied an important position, whereas during the second period (2014-2015) they became marginal. Instead, the topics of the Ukrainian crisis and related economic sanctions, import substitution, and securitization gained significant coverage. This shift happened primarily at the expense of the marginalization of other topics. The topics of regional activities and further cooperation for oil and gas exploration (including prominent mention of (hina) appeared rather uniformly throughout both periods.

Figure 1. Topic coverage in federal newspapers in two periods (source: author). 


\section{Federal 2011-2013 Federal 2014-2015}
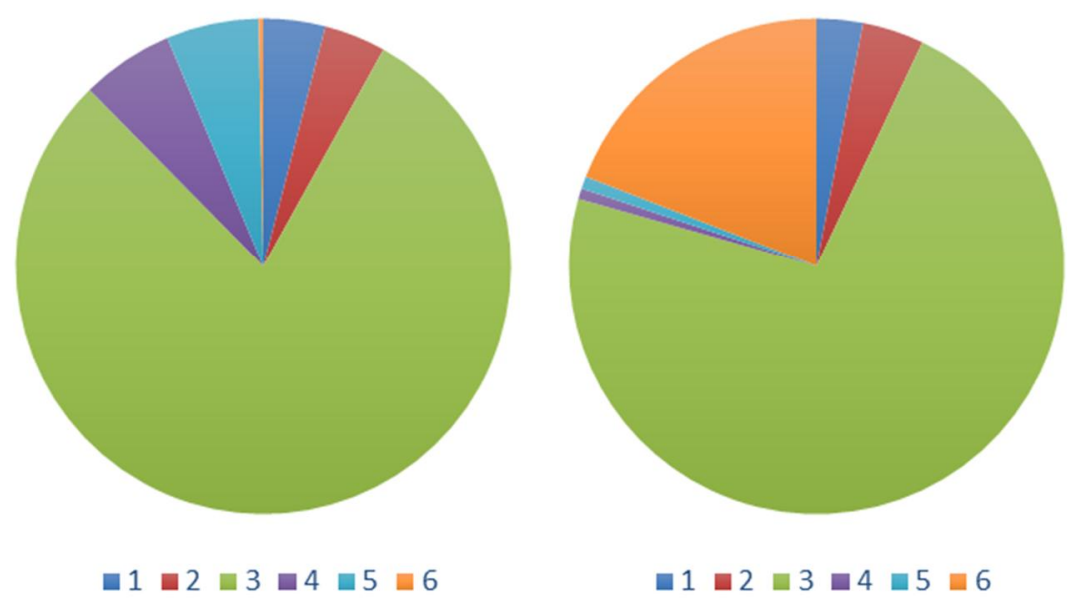

Fig. 2 illustrates the change in topic coverage in the regional press. First, the same tendencies were observed as were seen in the federal newspapers, i.e., there was one dominant topic that received significant coverage during both periods, in this case the role of Arctic resource-rich regions in Russian economic development. Second, in the second period one new topic attained significant attention (\#6, regional development after sanctions), at the "expense" of other issues that were toned down (Topics \#1, \#2, \#4). Finally, the topic that covered a broad spectrum of issues pertaining to regional socio-economic development (Topic \#5) received more attention during the second period.

Figure 2. Topic coverage in regional newspapers in two periods (source: author).

Regional 2011-2013

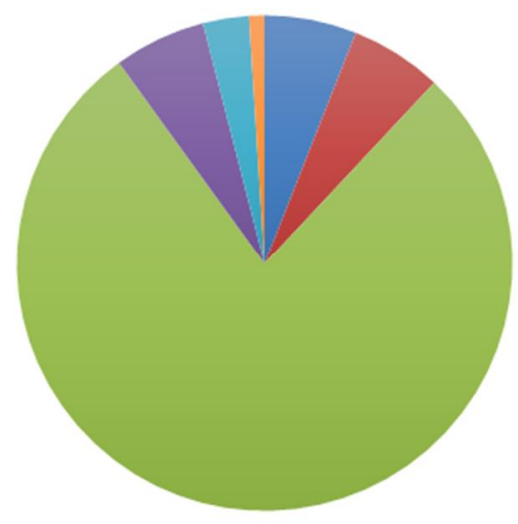

$\square 1 \square 2 \square 3 \square 4 \square 5 \square 6$

\section{Regional 2014-2015}

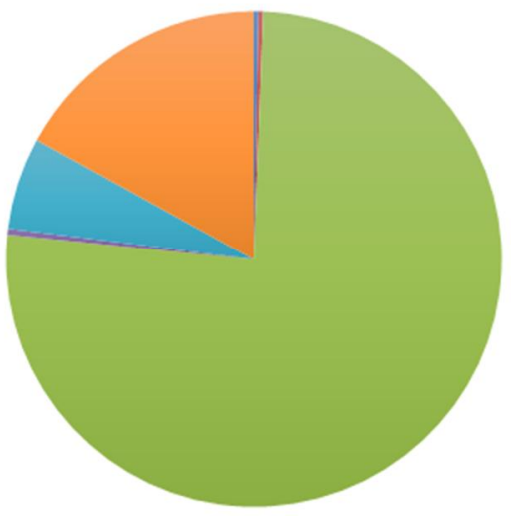

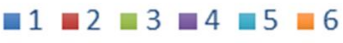




\section{Discussion}

The analysis of topic structures in Russian newspapers suggested that the Arctic was primarily discussed in relation to the development of hydrocarbon energy resources during 2011-2015. The vision of the Russian Arctic as a thriving economic hub for energy production is in line with the main rationale of the Russian Arctic policy as communicated in strategic documents issued by the federal government: to transform the Arctic into Russia's "foremost strategic base for natural resources" (Russian Arctic Policy, 2008). However, the realization of this goal by 2020, as initially envisaged, will in all likelihood not match the reality, because Arctic energy development remains an area of high uncertainty that requires advanced technology and significant investments. This does not mean, however, that Arctic energy projects will be abandoned. Rather, we may expect changing patterns of development: new partners, as is the case with Chinese investors in the Yamal LNG projects, new priority projects with adjusted timetables, and more focus on intensive onshore rather than extensive offshore development. Arctic energy development, as with other large infrastructure projects, shall be understood in terms of politics as much as in terms of economics. Even though commercial viability may seem weak, some projects may receive subsidies as the Russian government seeks to maintain its position in the global energy markets and/or gain momentum in the growing Asian and other emerging markets.

The media analysis also indicated that the repercussions of the Ukrainian conflict and tensions in Russian relationships with the West should be taken into consideration. The introduction of economic sanctions has compromised Russia's ambitions for attaining rapid economic growth and development in the Arctic. The launch of large-scale import substitution requires not only mobilization of internal capacity for research and development $(R \& D)$ and technology production, but also the ability to align with other powers. The federal media sources indicated that securitization rhetoric has strengthened in the coverage of Arctic-related activities. The regional newspapers also shifted their agenda toward a more "introverted" approach to regional development. The economic and political consequences of the Ukrainian crisis put a greater emphasis on Russia's internal capacity to develop ( $R \& D$, industry) and protect (security, search and rescue, army bases, and patrolling) the strategic energy projects in the Arctic. At the same time, the new international situation has forced Russia to diversify their sources of investment and industrial cooperation by turning to new partners, in particular those from Southeast Asia.

In summation, this study illustrates how Russian media performs a function of translating the central messages of Russian governmental strategies, as well as how this process was influenced by a crisis that was external in focus. Prior to the Ukrainian crisis and the strong decrease in oil prices, Russia promoted an international approach to Arctic development while strictly safeguarding its sovereignty in the region. As a result of the growing confrontation with the West and the introduction of economic sanctions and countersanctions, Russian focus on the Arctic as a future resource base has not shifted, yet directions of economic cooperation have been reconsidered. This study can be seen as a first step toward a more in-depth analysis. For instance, a sentiment or a frame analysis that would allow not only for the mapping of topics and establishing of their importance, but also for uncovering issue salience within the topics and their impact on public opinion. 


\section{Acknowledgments}

The author would like to thank Professor Veli-Pekka Tynkkynen, the reviewers, and the editor of the special issue for their constructive criticism and comments on the previous version of this paper. A special acknowledgment is to the chief editor for the helpful suggestion on the title. This research was presented in the Arctic Frontiers 2016 conference (January 24-29, Tromso, Norway), where it was warded the Nansen Poster Award for Early Career Scientists.

\section{References}

[1] M. Laruelle

Russia's Arctic Strategies and the Future of the Far North

M.E. Sharpe, NY, Armonk (2014)

[2] Russian Federation's State Policy in the Arctic until 2020 and beyond, 2009. Rossiiskaya Gazeta (M oscow) N 4877, 27.03.2009. http:// www.arctis-search.com/Russian+Federation+Policy+for the+Arctic+to+2020.

[3] A. Magomedov

Russia's plans for the Northern Sea Route: prospects and obstacles

Russ. Anal. Dig., 129 (2013), pp. 7-10

View Record in Scopus

[4] R. Howard

The Arctic Gold Rush: The New Race for Tomorrow's Natural Resources

A\&C Black (2009)

[5] J. Kraska

International security and international law in the northwest passage

Vanderbilt J. Transnatl. Law, 42 (2009), pp. 1109-1132

View Record in Scopus

[6] L. Aron

The Political Economy of Russian Oil and Gas

American Enterprise Institute (2013)

11

[7] A. Molis, M. Ogrodowski

Security implications of Russian energy policy. A view from the Baltic States

S. Oxenstierna, V.-P. Tynkkynen (Eds.), Russian Energy and Security up to 2030, Routledge (2013), pp. 114128 
[8] K. Zysk

Russia's arctic strategy: ambitions and constraints

Jt. Force Q., 57 (2010), p. 103

View Record in Scopus

[9] M. Carlsson, N. Granholm

Russia and the Arctic

Swedish Defense M inistry: Department of Defense Analysis (2013)

[10] Heininen, L., Sergunin, A., 2014. (Хейнинен и Сергунин). Политика России в Арктике: Как избежать новой Холодной Войны? Доклад Международного дискуссионного клуба "Валдай".

[11] Keil Kathrin

The Arctic: a new region of conflict? The case of oil and gas

Coop. Confl., 49 (2) (2014), pp. 162-190

[12] E. Klimenko, Russia's Evolving Arctic Strategy: Drivers, Challenges and New Opportunities. SIPRI Policy Paper 42: 17, 2014.

[13] G. Fouche

Wary of Russia, Norway urges NATO vigilance in Arctic, Reuters, 20.03.2014

(2014)

http:// www.reuters.com/article/2014/ 05/20/us-norway-defence-russia-idUSBREA4J0HE20140520

\section{[14] CBC News}

Canada boycotts Arctic Council M oscow meeting over Ukraine. The Canadian Press, 16.04.2014 (2014)

http:// www.cbc.ca/news/ canada/ north/canada-boycotts-arctic-council-moscow-meeting-over-ukraine1.2611964

[15] S. Norris

Despite Crimea, Western-Russian cooperation in the Arctic should continue. Carnegie.ru Commentary, 27.03.2014

(2014)

http://carnegieendowment.org/2014/03/27/despite-crimea-western-russian-cooperation-in-arcticshould-continue

[16] P. Aalto, T. Forsberg

The structuration of Russia's geo-economy under economic sanctions

Asia Eur. J. (2015), pp. 1-17

View Record in Scopus 
[17] P. Aalto

M odernisation of the Russian energy sector: constraints on utilising Arctic offshore oil Resources

Eur.-Asia Stud., 68 (1) (2016), pp. 38-63

CrossRefView Record in Scopus

[18] Russian Federation Arctic Zone Development and National Security Strategy up to 2020, 2013. Adopted by presidential decree 20.02.2013. http://government.ru/info/18360/ (Стратегия развития Арктической зоны Российской Федерации и обеспечения национальной безопасности на период до 2020 года).

[19] Russian Federation Energy Strategy up to 2035, 2014. Project. http://minenergo.gov.ru/upload/iblock/621/621d81f0fb5a11919f912bfafb3248d6.pdf (Энергетическая стратегия России на период до 2035 года).

[20] Russian Federation National Security Strategy up to 2020, 2009. Adopted by presidential decree no. 537, 12.05.2009. http://www.scrf.gov.ru/documents/99.html (Стратегия национальной безопасности Российской Федерации до 2020 года).

[21] P.W. Lackenbauer

M irror images? Canada, Russia, and the circumpolar world

Int. J. (2010), pp. 879-897

CrossRefView Record in Scopus

[22] M. Laruelle

Russian military presence in the high north: projection of power and capacities of action

S. Blank (Ed.), Russia in the Arctic, Strategic Studies Institute, Carlisle (2011), pp. 63-89

View Record in Scopus

[23] P. Johnston

Arctic energy resources: security and environmental implications

J. Strateg. Secur., 5 (3) (2012), p. 5

View Record in Scopus

[24] R. Kefferputz

On thin ice? (M is)interpreting Russian policy in the High North

CEPS Policy Brief, 205 (2010), pp. 1-10

View Record in Scopus

[25] E. Wilson Rowe

A dangerous space? Unpacking state and media discourses on the Arctic

Polar Geogr., 36 (3) (2013), pp. 232-244

CrossRefView Record in Scopus 
[26] N. Kovalyova

Unlearning the Soviet Tongue: Discursive Practices of a Democratizing Polity

Lexington Books (2014)

[27] K. Ognyanova

Careful what you say: media control in Putin's Russia-implications for online content

Int. J. E-Politics, 1 (2) (2010), pp. 1-15

CrossRefView Record in Scopus

[28] B. Etling, H. Roberts, R. Faris

Blogs as an Alternative Public Sphere: The Role of Blogs, Mainstream Media, and TV in Russia's Media Ecology. Berkman Center Research Publication No. 2014-8

(2014)

Available at SSRN:

http://ssrn.com/abstract=2427932

[29] M. Steyvers, T. Griffiths

Probabilistic topic models

T. Landauer, D. M cNamara, S. Dennis, W. Kintsch (Eds.), Handbook of Latent Semantic Analysis, Erlbaum, Hillsdale, NJ (2007), pp. 427-448

View Record in Scopus

[30] O. Koltsova, S. Koltcov

Mapping the public agenda with topic modeling: the case of the Russian livejournal

Policy \& Internet, 5 (2) (2013), pp. 207-227

CrossRefView Record in Scopus

[31] D.M. Blei

Probabilistic topic models

Commun. ACM , 55 (4) (2012), pp. 77-84

CrossRefView Record in Scopus

1 In Russia since 2000, the government's political control over national TV networks, printed press, and Internet outlets has been tightening in order to maintain oversight over a key mechanism of social and political agenda formation [27]. The studies found that traditional (print) newspapers in Russia particularly tended to be similar to government sources [28]. 